\title{
Exploring the green purchasing behavior of young generation in Pakistan: opportunities for green entrepreneurship
}

\author{
Raheem Bux Soomro and Irfan Ali Mirani \\ Institute of Business Administration, \\ Shah Abdul Latif University, Khairpur, Pakistan \\ Mirani Sajid Ali \\ Department of Public Administration, \\ Shah Abdul Latif University, Khairpur, Pakistan, and \\ Soomro Marvi \\ Institute of Business Administration, \\ Shah Abdul Latif University, Khairpur, Pakistan
}

Exploring the green

purchasing behavior

\begin{abstract}
Purpose - This paper aims to assess the impact of green purchasing behavior (GPB) of a young generation in Pakistan.

Design/methodology/approach - The data were collected from students of different colleges affiliated with Shah Abdul Latif University from Sukkur and Larkana regions of Upper Sindh. A total of 400 questionnaires were administrated among students and 361 completed questionnaires were returned. A penand-paper method was applied to collect the data.

Findings - Model 1 revels that interpersonal influence and environmental knowledge were found positively related to GPB, whereas media and price were found positively but insignificantly related to GPB. Lastly, trust in green products was also found negatively and insignificantly related with GPB. Model 2 was used to test the moderating impact of price on the relationship between EA and GPB.

Practical implications - To promote GPB, government can play significant role by sponsoring environmental campaigns and environmental culture and these campaigns may include broadcasting promotional messages, distributing leaflets with utility bills, speeches in schools and colleges and advertisements with the help of printing and electronic sources.

Originality/value - Regarding green food purchase, this study's results contribute to the literature by providing some theoretical contributions in literature. Green purchasing is so far a very new notion in Pakistan and therefore, literature on promotion of GPB is still lacking in the said country.
\end{abstract}

Keywords Factor analysis, SPSS, Young consumers, Environmental attitude,

Green purchasing behavior, Interpersonal influence

Paper type Research paper

(C) Raheem Bux Soomro, Irfan Ali Mirani, Mirani Sajid Ali and Soomro Marvi. Published in Asia Pacific Journal of Innovation and Entrepreneurship. Published by Emerald Publishing Limited. This article is published under the Creative Commons Attribution (CC BY 4.0) licence. Anyone may reproduce, distribute, translate and create derivative works of this article (for both commercial and non-commercial purposes), subject to full attribution to the original publication and authors. The full terms of this licence maybe seen at http://creativecommons.org/licences/by/4.0/legalcode. 


\section{APJIE 14,3}

\section{Introduction}

Human consumption patterns have been changed owing to a quick growth in world population, which has affected directly and indirectly the well-being of population. This consumption has created several potential damages to the environment such as global warming, increased environmental pollution and decline in flora and fauna (Chen and Chai, 2010). Throughout time, health of people at a community and an individual level has been affected by environmental difficulties. Because of these reasons, customers are becoming more apprehensive in their environmental preferences, purchases and attitudes. Green purchasing behavior (GPB) refers to purchasing environmentally friendly products also referred to as sustainable products or green products. On the other side, normally green consumption is associated to an environmentally responsible pattern of consumption where customers ponder the impact of buying, using and disposing of numerous goods or consuming numerous green services in an environment. Green products have been defined by other researchers as products which do not cause pollution on Earth or natural resources' depletion, and can also be recycled. Since several years, various international organizations have begun to manufacture green products and a sizeable number of individuals are ready to welcome these green products. However, in accordance with Young et al. (2010), this enhanced willingness of individuals has not been found to convert into action. Since past few years, a willingness of several individuals to buying green products has increased and there is a slight evidence to propose that green products' buying has increased. Despite concerns for environment and customers' positive attitude to green products and sustainability, market share of green products remains limited to just $1-3 \%$ of the whole market. A weak relation has been observed by the majority of earlier studies between consumers expressed positive attitude toward green buying and their actual buying behavior (Vermeir and Verbeke, 2008). This proposes that considerations for the environment do not essentially play a main part in buying decisions of consumers and individuals usually oversee impact of the environment on their purchases. Since the past 30 years, widespread research has been done to find out the factors of ethical consumer behavior. To completely comprehend the details of sustainable marketing, young customers - being the decision-makers of the future - are perfect individuals in this domain. Environmental protection around the world has led to extensive attention from the academia while green entrepreneurship has been regarded as the solution to environmental and social problems (Hall et al., 2010). In accordance with Deloitte (2014), young customers are usually much attracted in consuming environmentally friendly products. Because of these reasons, it is vital for organizations and governments' planning to identify knowledge, attitudes and buying behaviors of green products and plans to encourage concern and behaviors for green purchase (Dagher and Itani, 2012).

Pakistan is as of late confronting various genuine natural issues, which are of extraordinary environmental worry as far as its manageable financial future. These join soil deterioration, pesticide mishandle, deforestation, desertification, urban tainting, waterlogging and saltiness, freshwater sullying and marine water pollution and a couple of others. Because of these environmental problems, during summer, the normal/average temperature in various parts of Upper Sindh remains above $40^{\circ} \mathrm{C}$ and some time it crosses $50^{\circ} \mathrm{C}$. Owing to this situation, there is a dire need to explore buying behavior of a young generation belonging to the region and also to educate and motivate them to buy green products. The respondents for this study were young people (15-32 years) as they account for more than $50 \%$ of the population of Pakistan. In accordance with Dawn, Pakistan has the largest percentage of young people in its history (Zafar, 2020). Youthful buyers can be the main impetus that achieves the change that is wanted regarding capable utilization designs. The first objective of this study is to find out up to what degree youth is aware of environmental problems in Upper Sindh. Second objective is what youth think about these 
issues. Last objective is exploring whether youth is concerned or not for buying green products.

The first section of this paper is about the introduction while a review of literature along with hypotheses has been provided in the second section. The third section contains sampling, procedures for data collection, measures and their variables. The fourth section covers regression models for testing hypotheses. In the fifth section, hypotheses of the study were tested using SPSS (24). In the last section, theoretical and practical implications and limitations have been presented.

\section{Literature review and hypotheses development Green purchasing behavior}

Green purchasing can be defined as the purchasing of those products which are environmentally friendly and evading those products which are harmful to the environment. Furthermore, it is a green product, which fulfills consumers' needs without doing damage to the environment and contributes toward a sustainable world. The said products possess low environmental impact and are environmentally superior. According to Chen and Chai (2010), green products consume material which is safer to the environment, are also recyclable and need fewer packaging. A few models of green products are homegrown items, natural items, vitality proficient lights, eco-accommodating clothes washer and so forth. GPB is another important point to consider here.

\section{Environmental knowledge and green purchasing behavior}

Kaufmann et al. (2012) defines environmental knowledge (EK) as it is up to what level people know the environment with regard to how the product is produced, how a product affects the environment and how shared responsibility is essential for sustainable development. Customer knowledge of the Earth incorporates the nursery impact, squander administration, dangerous waste and reused materials. Mostafa (2009) found an important relation between green consumer behavior and EK. EK plays a multifaceted role in inducing the individual's behavior. The possession of knowledge about the environment by consumers aids them in assessing consumers' green behavior and proposing action strategies (Cheah and Phau, 2011). If a consumer possesses knowledge for the causes and their effects on the environment than their level of awareness will enhance and encourage a favorable attitude to green products significantly. In addition, shoppers' environmental concern had the significant effect on their ability to pay for environmentally agreeable items (Xu et al., 2020). However, other researcher found that there is an inconclusive influence of EK on attitude to buy environment friendly products. Henceforth, the following hypothesis has been made:

H1. Young consumers' EK significantly and positively affects their GPB.

\section{Interpersonal influence and green purchasing behavior}

"An issue of susceptibility of consumers to interpersonal influences is one of the most extensively applied behavior-theoretical frameworks in the studies of social psychology and consumer behavior" (Shukla, 2011). Interpersonal influence (IPI) motivates and develops beliefs and attitudes of people. Further, it is also thought that IPI is a factor of behavior of an individual (Cheah and Phau, 2011). According to the literature, informational IPIs and normative IPIs are two wide classes of consumers' susceptibility to IPIs. Informational IPI can be explained as an inclination to acknowledge information as evidence of reality from 
APJIE 14,3

others. Whereas, normative IPIs are mentioned as the conformity to the norms and expectations of others in all conditions. Family and friends are sources of consumers' knowledge for environmentally friendly products (Cheah and Phau, 2011). In the same way, there is evidence that consumers' attitude to environment friendly green products is affected by norms and social groups. In this regard, Khare (2012) explained that there is a positive relation between IPI and environmental attitude. Therefore, $H 2$ has been proposed here:

H2. IPI among youth significantly and positively affects their GPB.

\section{Trust and green purchasing behavior}

Trust can be defined as the degree of hope possessed by one party that can trust on the promise, statement or word of another party. Integrity, ability and benevolence are the three outcomes of trust. Therefore, trust is a level of the willingness to keep a belief in other party based on the expectation about the ability, reliability and benevolence of that party. In the context of green products, Chen (2013) defines trust as someone's expectation or belief for the environmental performance of these products. In the event that clients have just had a pleasant involvement with the results of sellers, they would frame a more elevated amount of trust on their items. A few firms misrepresent or even create the ecological execution of their items, and in this manner, clients are not willing to confide in them any longer. Hence, green trust is more vital in these days. According to Joshi and Rahman (2015), 6 research studies out of 53 observed that there is an influence of trust on customer's purchase intention and behavior. Hence, it may be said that absence of customer trust in green items goes about as a boundary toward green buy conduct. In the light of above discourse, following hypothesis has been made:

H3. There is a negative and insignificant relation between trust and GPB.

\section{Media exposure and green purchasing behavior}

Exposure to media is an important tool to promote GPB among young people. Mass media affect the preference and perception of young customers for various products. Lee (2014) stated that environmental messages dispersed by media affect purchasing behavior of customers toward sustainable products. Therefore, it can be argued that environmental messages exposed by media affect environmental concerns of consumers positively. Green promoting influences singular perspectives toward publicizing and their aim to be agreeable to the environment (Kim et al., 2019). The media is highly powerful and can rise significant environmental issues and these can impact the consumers' thinking process. Further, media owns the power to effect social norm. In media introduction, individuals from the media proliferate ecological assurance worries by quickly offering significant learning to the general population. Green items can be promoted in television (TV) commercials; nevertheless, print notices may encourage the sharing of itemized data and build up item picture acknowledgment among shoppers. Thus, we hypothesize:

H4. Messages communicated by media will positively affect GPB of youth.

\section{Moderating role of price transparency}

The product data (for example, cost and quality) was viewed as a determinant of the shoppers' green buy conduct (Cheung and To, 2019). While making their decisions for 
buying organic food, consumers consider price as a vital factor (Padel and Foster, 2005). Mittal and Agrawal (2016) defined price transparency as a clear indication on current price and according to past research studies, price transparency is a significant feature of price satisfaction. Price transparency empowers purchasers to estimate and assess the overall engaging quality of the organization's current offer (i.e. the client's thought of the cost paid) when contrasted with other serious proposals in the market (Hanna et al., 2019). Similarly, price transparency can be defined as a customer's access to comprehensive, clear and correct information about the price of a product (Matzler et al., 2006). Furthermore, transparency in price also influences satisfaction of customers indirectly (Matzler et al., 2006) because positive judgment can enhance satisfaction of customers and their loyalty for a product. In the same way, shortage of consumers' economic resources was found expanding the impact of price as a blockade to buy green products. On the contrary, it was found that consumers' low-price sensitivity affects GPB positively (Eze and Ndubisi, 2013). In conclusion, it can be said that high price sensitivity impacts consumers' GPB negatively. Because of the above literature, following hypothesis has been proposed:

H5. Price transparency moderates the relation between environmental attitude and consumers' GPB.

\section{Gender and green purchasing behavior}

The basic concept behind consumption of green product is environmental conservation and reduction of effect of human activities on the natural environment (Obayelu, 2016). Consequently, customers have become much familiar with the risk encountered by the environment and their direct and indirect effects for life on Earth on a short- and long-term basis (Kraft, 2017). Lee (2009) expressed the opinion that Chinese young females were rated meaningfully higher than young Chinese males in GPB. In the same way Han et al. (2011) were of the opinion that females portrayed higher intention for using a green hotel as well as recommending it to others and paying higher prices for it. On the contrary, some research studies did not find any relation between gender and environmental behavior (Berenguer et al., 2005). Thus, our sixth hypothesis in this study is as follows:

\section{H6. Female consumers show higher GPB than their counterparts.}

The hypothesized conceptual framework of this research work is shown in Figure 1.

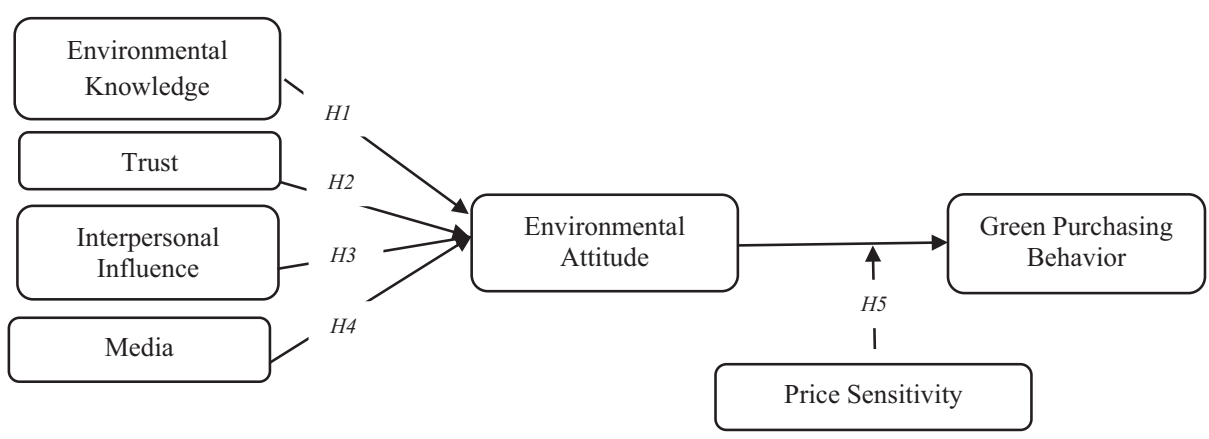

Figure 1.

Hypothesized theoretical framework of this study 


\section{APJIE 14,3}

294

\section{Methodology}

Questionnaire and measures

A self-administered questionnaire was used to collect data from young respondents. Measures of the survey were borrowed from previous studies, which are shown in Table 1. As the medium of instruction was English among targeted colleges, therefore, questionnaire was developed in English language. The questionnaire was divided in two parts. The first part of the questionnaire contained all closed-ended variables and they were measured by using five-point Likert scale ranging from 1 (strongly disagree) to 5 (strongly agree). The second part was consisting of demographic information of respondents.

The data were collected from students of different colleges affiliated with Shah Abdul Latif University (SALU) from Sukkur and Larkana regions of Upper Sindh. More than 75 colleges are affiliated with SALU and physically it was not possible to reach all colleges. Therefore, those colleges, located in big cities of Upper Sindh were chosen. Different teams of volunteers were formed to collect data from chosen affiliated colleges located in the big cities of the said regions through a random sampling technique. Before administrating the questionnaire, the team members got the participants familiarized with images of green products (such as beauty, dairy and cheese, grocery, poultry and eggs, salad and herbs and skin and body care products). In total, 400 questionnaires were personally administrated among students; however, students returned only 361 completed questionnaires. A pen-andpaper method was applied to collect data from the students admitted in targeted colleges. A profile of respondents is shown in Table 2.

\section{Analysis and results}

SPSS (V. 24) was used to compute both the scale reliability and factor analysis. Cronbach's $\alpha$ value of 0.829 for the multi-item scale was found, which demonstrates acceptable internal reliability. Further, reliability of all sub-scales was measured. The range of values of reliability was from 0.755 to 0.979 , which allows us to accept these values. According to Nunnally and Bernstein (1994), if score is exceeding 0.7 it indicates high internal reliability of the scale items, but there are still researchers who use different cut-off R-scores such as 0.8 or even 0.6 (Garson, 2002).

The Kaiser-Meyer-Olkin measure of sampling adequacy was 0.821, which is over an adequate level. Communalities of all factors were moderately high, ranging from 0.415 to 0.955. This implies the factors fitted well with different factors in their groups. To produce the groups, a principal component analysis with varimax rotation was used. Every item with loading of above 0.50 was accepted. When the principal component analysis with varimax rotation was applied on variables, these variables were grouped in several headings. Table 3 portrays the results of factor analysis, and this factor analysis was performed by using principal component analysis with varimax rotation.

\begin{tabular}{lcl}
\hline Measures & Item nos. & Source \\
\hline GPB & 7 items & Chen (2010) \\
Trust on green products & 5 items & Chen (2010) \\
EK & 6 items & Joshi and Rahman (2016) \\
IPI & 8 items & Bearden et al. (1989) \\
Price transparency & 5 items & Mohr et al. (1998) \\
Media & 4 items & Kaman (2009) \\
Note: Sample and administration of the survey & & \\
\hline
\end{tabular}

Table 1.

List of measures and their sources

Note: Sample and administration of the survey 


\begin{tabular}{|c|c|c|c|}
\hline Details of students & Frequency(s) & $(\%)$ & oree \\
\hline $\begin{array}{l}\text { Gender } \\
\text { Male } \\
\text { Female } \\
\text { Total }\end{array}$ & $\begin{array}{l}234 \\
127 \\
361\end{array}$ & $\begin{array}{c}64.8 \\
35.2 \\
100.0\end{array}$ & $\begin{array}{r}\text { purchasing } \\
\text { behavior }\end{array}$ \\
\hline $\begin{array}{l}\text { Age } \\
15-18 \\
19-21 \\
22-25 \\
26-28 \\
29 \text { and over } \\
\text { Total }\end{array}$ & $\begin{array}{c}54 \\
84 \\
148 \\
61 \\
14 \\
361\end{array}$ & $\begin{array}{c}15.0 \\
23.3 \\
41.0 \\
16.9 \\
3.9 \\
100.0\end{array}$ & 295 \\
\hline $\begin{array}{l}\text { Education } \\
\text { Intermediate } \\
\text { Graduation } \\
\text { Post-graduation } \\
\text { Total }\end{array}$ & $\begin{array}{c}117 \\
181 \\
63 \\
361\end{array}$ & $\begin{array}{c}32.4 \\
50.1 \\
17.5 \\
100.0\end{array}$ & \\
\hline $\begin{array}{l}\text { Family monthly income } \\
\text { Up to } 25,000 \\
26,000-50,000 \\
51,000-100,000 \\
100,001-150,000 \\
150,000 \text { and above } \\
\text { Total }\end{array}$ & $\begin{array}{c}61 \\
161 \\
29 \\
57 \\
53 \\
361\end{array}$ & $\begin{array}{c}16.9 \\
44.6 \\
8.0 \\
15.8 \\
14.7 \\
100.0\end{array}$ & $\begin{array}{r}\text { Table } 2 . \\
\text { Profile of the } \\
\text { respondents }\end{array}$ \\
\hline
\end{tabular}

The results of correlation are given in Table 4 where all variables are positively correlated with each other. The strength of correlations of GBP, media and price is lesser as compared to other variables. IPI is strongly and significantly correlated with other variables. Based on the studies of Baron and Kenny as well as Cohen and Cohen, hierarchical regression analysis was used to test H1, H2, H3, H4 and H5 (Baron and Kenny, 1986).

SPSS 24 was used to test two linear regression models and results are shown in Table 4. Model 1 regressed the dependent variable (GPB) on the independent variables (media, price, EK, IPI and trust on green products). Model 2 regressed the dependent variable (GPB) on the independent variables (media, price, EK, IPI and trust on green products), and also on the interaction's terms between environmental attitude and price to test the moderation effects of price.

Model 1 (Table 5) finds that IPI $(\beta=0.40, t=7.04, p<0.05)$ and $\operatorname{EK}(\beta=0.24, t=5.26, p$ $<0.05)$ are positively related to GPB. Moreover, media $(\beta=0.01, t=3.41, p>0.05)$ and price ( $\beta=0.02, t=6.16, p>0.05$ ) were found positively but insignificantly related to GPB. Trust on green products $(\beta=-0.01, t=-4.176, p>0.05)$ was found negatively and insignificantly related with GPB. The $R^{2}$ for Model 1 was 0.237 . Model 2 was used to test the moderating impact of price on the relationships between EA and GPB. Examination of the moderating variable path coefficients in Table 5 showed that price insignificantly influenced the effects between environmental attitude and GPB $\left(\beta_{\text {PricexEA }}=0.01, t=1.67, p>0.5\right)$, which did not support $H 6$. The $R^{2}$ for Model 2 is 0.243 .

Table 6 portrays the results of Levene's test for equality of variance for gender. The said test is non-significant because of $p=0.510$, which is higher than 0.05 . This result portrays an insignificant difference between the male (mean $=9.39)$ and female $($ mean $=9.02)$ toward 


\begin{tabular}{|c|c|c|c|c|c|c|}
\hline $\begin{array}{l}\text { APJIE } \\
14,3\end{array}$ & Variables & Indicators & Loadings & $\begin{array}{c}\text { Cronbach's } \\
\text { alpha }\end{array}$ & $\begin{array}{l}\text { Eigen } \\
\text { values }\end{array}$ & $\begin{array}{c}\text { Variance } \\
\text { explained (\%) }\end{array}$ \\
\hline 296 & IPI & $\begin{array}{l}\text { Int_Pers05 } \\
\text { Int_Pers03 } \\
\text { Int_Pers02 } \\
\text { Int_Pers01 } \\
\text { Int_Pers04 } \\
\text { Int Pers08 }\end{array}$ & $\begin{array}{l}0.976 \\
0.969 \\
0.964 \\
0.962 \\
0.917 \\
0.915\end{array}$ & 0.979 & 5.563 & 20.603 \\
\hline & Price & $\begin{array}{l}\text { Price03 } \\
\text { Price04 } \\
\text { Price05 } \\
\text { Price02 }\end{array}$ & $\begin{array}{l}0.969 \\
0.966 \\
0.910 \\
0.881\end{array}$ & 0.949 & 4.664 & 17.275 \\
\hline & Media & $\begin{array}{l}\text { Media01 } \\
\text { Media03 } \\
\text { Media04 }\end{array}$ & $\begin{array}{l}0.976 \\
0.956 \\
0.941\end{array}$ & 0.956 & 3.443 & 12.751 \\
\hline & EK & $\begin{array}{l}\text { EK04 } \\
\text { EK06 } \\
\text { EK01 } \\
\text { EK02 } \\
\text { EK03 }\end{array}$ & $\begin{array}{l}0.772 \\
0.726 \\
0.698 \\
0.635 \\
0.600\end{array}$ & 0.755 & 2.676 & 9.911 \\
\hline & Trust on green products & $\begin{array}{l}\text { TGP01 } \\
\text { TGP06 } \\
\text { TGP03 } \\
\text { TGP05 }\end{array}$ & $\begin{array}{l}0.777 \\
0.772 \\
0.736 \\
0.705\end{array}$ & 0.799 & 1.828 & 6.772 \\
\hline $\begin{array}{l}\text { Table } 3 \text {. } \\
\text { Factor analysis }\end{array}$ & GPB & $\begin{array}{l}\text { GPB01 } \\
\text { GPB03 } \\
\text { GPB05 } \\
\text { GPB06 } \\
\text { GPB02 }\end{array}$ & $\begin{array}{l}0.774 \\
0.766 \\
0.706 \\
0.514 \\
0.511\end{array}$ & 0.757 & 1.416 & 5.243 \\
\hline
\end{tabular}

GPB. Therefore, there is sufficient evidence to reject $H 6$ and it can now be said that the GPB of a male is similar to a female.

\section{Discussion and conclusion}

Major environmental issues and exhaustion of normal assets constrained human progress to center around the Earth's mindful utilization. It is mentioned in previous studies that a gap exists in literature owing to a shortage of studies on assessing the impact GPB of consumers (Young et al., 2010). Keeping in view this gap, one of the basic objectives of this paper was to explore the main factors that influence the GPB of young customers in Sindh, Pakistan.

\begin{tabular}{|c|c|c|c|c|c|c|c|c|}
\hline N 381 & Mean & $\mathrm{SD}$ & 1 & 2 & 3 & 4 & 5 & 6 \\
\hline GPB & 9.2587 & 3.48 & 1 & & & & & \\
\hline Media & 7.5937 & 2.92 & 0.087 & 1 & & & & \\
\hline Price & 10.6641 & 3.75 & 0.055 & 0.045 & 1 & & & \\
\hline TGP & 13.3416 & 6.07 & 0.019 & 0.050 & 0.008 & 1 & & \\
\hline IPI & 6.6212 & 2.96 & 0.417 ** & 0.103 & 0.042 & 0.058 & 1 & \\
\hline EK & 9.8654 & 3.63 & $0.357^{* * *}$ & $0.138 * *$ & 0.043 & 0.068 & $0.286 * *$ & 1 \\
\hline
\end{tabular}

Correlations among variables of study

Note: Correlation values are significant at: **0.01 levels 
Green purchasing is so far a very new notion in Pakistan and therefore, literature on promotion of GPB is still lacking (Figure 2).

This current study found that there is a strong and positive relationship between perceived EK and GPB. Likewise, this result is also in line with several previous research studies, which declared a positive relation between green consumption and EK exists (Mostafa, 2006; Young et al., 2010). It is mentioned in other studies that knowledge has influence on behavior through attitudes, and also stated a positive association between attitudes and EK (Cheah and Phau, 2006). On the contrary, no guarantee was reported that customers with high EK purchase products that are friendly to environment. Because of that reason, an importance should be given on transmitting a higher level of EK to encourage customers to follow sustainable actions and diminishing the negative effect on their

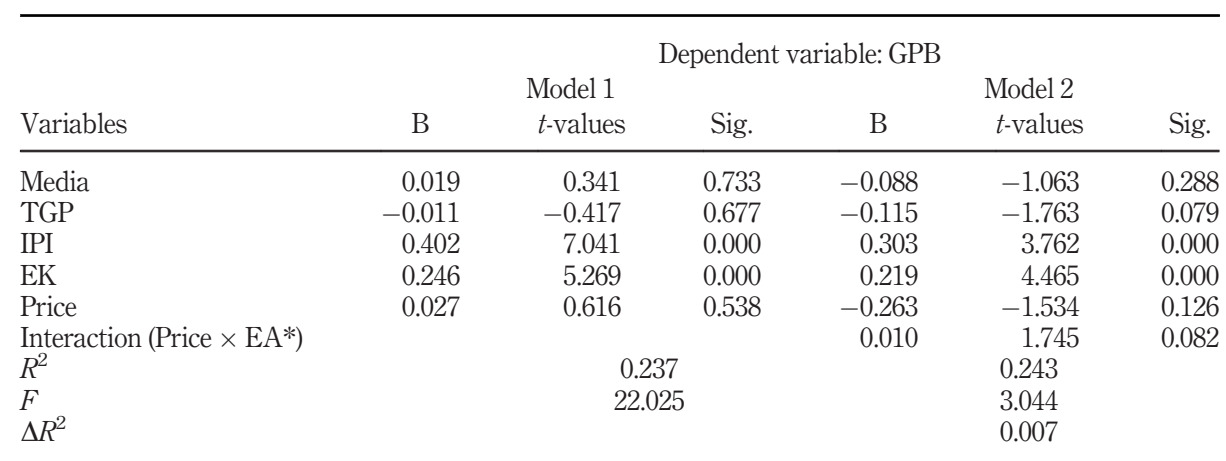

Notes: *Environmental attitude was computed by taking an average of all IVs. IPI: interpersonal influence; TGP: trust in green products; EK: environmental knowledge
Exploring the green purchasing behavior

\begin{tabular}{lcccc}
\hline & Male & Female & $p$-value & Decision \\
\hline$N$ & 243 & 127 & 0.05 & Accepted \\
Mean & 9.39 & 9.02 & & \\
Standard error mean & 0.2249 & 0.3159 & & \\
Standard deviation & 3.44 & 3.56 & & \\
\hline
\end{tabular}

Table 5.

Regression analysis

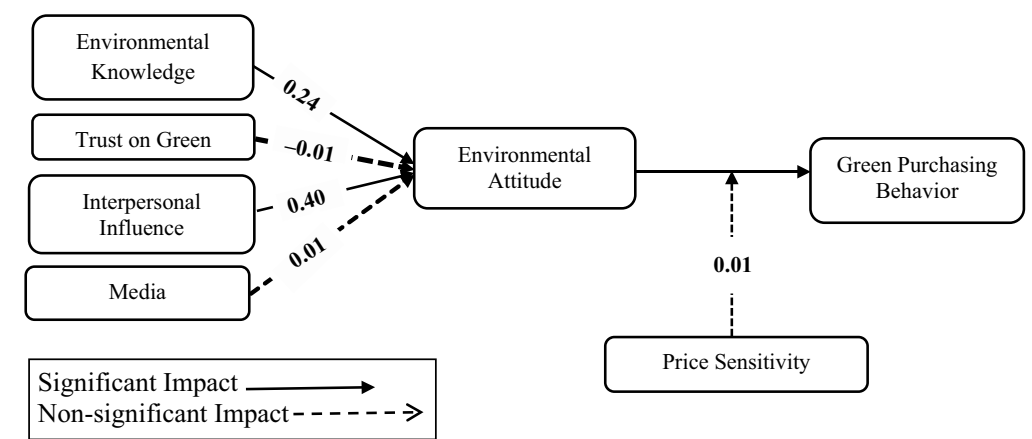

Figure 2. Research model with results 
APJIE 14,3

\section{8}

environmental consumption practice (Paradowska, 2014). This study also found that there is a strong and positive relationship between IPI and GPB. Our findings are similar to those of Cheah and Phau (2011) as they stated that those consumers who possess favorable attitude with environmentally friendly products are more probably to buy them. Added to this result, they explored that there is a strong correlation between interpersonal values and environmentally friendly products. Generally speaking, the media (for example, radio, magazines, bulletins and TV) have a solid capacity to induce the general population in purchasing environmentally friendly items and make them mindful of normal issues and environmental change issues. Nevertheless, a negative and insignificant relation has been reported in this study. This may be owing to inadequate coverage of green products through conventional media. As it was additionally detailed by Malik et al. (2019), no or uncommon advertisements were seen by the researchers in print or potentially electronic media. Therefore, it is very important to provide adequate coverage to a green product in different parts of Upper Sindh through various media sources. For that reason, a huge media attention should be allocated for different small problems associated with environment to make them public issues (Qader and Zainuddin, 2011). Although green trust is more important nowadays, but trust on green products was found negatively and insignificantly related with GPB. Green trust can be defined a willingness to depend on a brand, service or product based on the confidence or expectation resulting from its benevolence, credibility and ability about its environmental performance (Chen, 2010). As, it was informed earlier that respondents were shown images of green products before filling the questionnaire and these products may not be locally available in Upper Sindh. Therefore, it might be difficult for respondents to trust on credibility, benevolence and ability of said products and that is why most respondents shown lack of trust.

Generally, higher prices result in discouraging consumers' purchase behavior for all types of products. However, in this study, price does not moderate here and it means people who understand environmental issues are ready to pay higher prices for green products. In this connection, Table 1 (family income) tells us that the vast majority of respondents are belonging to higher income classes. Price is not the key concern for customers who possess a high degree of greenness and are eager to spend more for buying green products.

Lastly, the results of independent sample $t$-tests for gender indicated that there is no difference between purchasing behavior of male and females for green products in this maledominant society of Upper Sindh. Hence, this result provides additional encouragement for entrepreneurs to market more and more green products in this location. For that reason, it is the time now to advance strategies for green marketing because they are important to promote green products (Lim et al., 2013).

\section{Theoretical and practical contribution}

Regarding green food purchase, this study's results contribute to the literature by providing some theoretical contributions in literature. First, this research assists us to comprehend the role of various social variables, which are influencing the attitudes, perceptions and behavioral intentions of consumer regarding green products. Secondly, a gap was left by earlier research studies in literature owing to shortage of studies on assessing the impact of social influence on consumers' green purchase behaviour (Young et al., 2010).

Therefore, this study tries to fill this gap and creates a strong relation between social influence and GPB of young educated consumers. Lastly, by collecting data in Pakistan, this 
study tries to reply to the calls for supplementary research on the consumption of organic food in the context of emerging markets (Teng and Wang, 2015).

Youth in Pakistan accounts for about $60 \%$ of the population and can be potential customers for green products. This study demonstrates that young students in Upper Sindh have displayed quite a promising market opportunity for green entrepreneurship. As indicated by Demirel et al. (2019), green business enterprise improves firm execution through expanded straightforwardness, cost-proficiency, better risk management and income development because of item separation. Hence, local entrepreneurs are suggested to target young people because they hold sufficient buying power, possess enough authority to influence their friends and relatives, are ready to welcome inventive thoughts/products and because of longer life-range.

Further, government can also play its significant role by sponsoring environmental campaigns and promoting an environmental culture and these campaigns may include broadcasting promotional messages, printing advertisements, speeches in shopping centers and educational institutes (such as in schools and colleges) and distributing leaflets with magazines, newspapers and utility bills. Additionally, in Pakistani colleges/universities, the curriculum does not offer environmental mindfulness/direction-related subjects even at advanced education level (Malik et al., 2019). Because of this reason, educational institutes of all levels may offer environment-related courses and invite teams of professionals with adequate knowledge of environment and green products and effective communicational skills to participate in environment-related conferences, seminars and interviews for their students to make them aware about the importance of using green products. Additionally, governments may impose tough penalties on those who are involved in harmful activities to the environment. On the other hand, Lin and Chang (2012) stated that some customers perceive green products as less effective. To alter this perception, Aaker et al. (2010) suggested that organizations dealing in green products might recruit trustworthy sources to encourage the perceived effectiveness of green product and willingness of customer to purchase them. Lastly, government ought to likewise give essential finance to youthful business visionaries who need to enter in this field as fund to a business resembles oxygen to a man, in that without oxygen, one cannot endure (Orobia et al., 2020). Lack of access to finance is still a major constrain faced by the youth and women entrepreneurs in Pakistan.

Above recommendations are tools with which government and SMEs can promote green knowledge, attitudes, concern and behavior. Additionally, Government of Pakistan should also provide necessary finance to young people who want to start their business in providing green products to local consumers. Because, finance to a business is like oxygen to a man, in that without oxygen, one cannot survive (Orobia et al., 2020). Lack of access to finance is still a major constraint faced by the youth and women entrepreneurs in Pakistan. In this way, green word of mouth might be encouraged to boost effective environmental culture. The proposed limited time apparatuses, whenever applied appropriately, should bring about having individuals with more information, inspirational dispositions and more worry about ecological issues. Such individuals, at that point, would read more about ecological issues and discuss these more with companions and relatives, be more resolved to ensure the Earth maintains a strategic distance from exercises and items thought to be against the condition and incline toward green items.

\section{Limitations and further research}

Like any other study, this study is evident with some limitations. First, young customers are distinctive from various perspectives from kids or grown-ups in other age gatherings. For instance, youths are exceptionally powerless to enthusiastic interests. Owing to this reason,
Exploring the green purchasing behavior

299 
APJIE 14,3

discoveries of the present examination cannot be generalized to different fragments of the populace having a place with various age gatherings; youthful taught buyers would vary from purchasers falling under various age bunches in a few different ways (for example, reception of new thoughts and worry toward environment). Secondly, people live in the collectivist culture in Pakistan where social influence can be much influential and therefore, generalization of findings of this study to other cultural groups would be difficult. As this research study has been conducted in a developing country, henceforth, carefulness must be considered in explaining green consumption behaviors in the developed markets by following the findings of this study. Multi-method approach should be followed by future research studies in collecting data or conducting an objective evaluation of these variables (direct observation, etc.). Furthermore, future studies should use other psychometric variables, such as green loyalty, because they are frequently related with GPB. The present research has measured buying intentions of a young generation with regard to green products in general and future studies should measure the buying intentions of young generation to other green products in different areas of Pakistan.

\section{References}

Aaker, J., Vohs, K.D. and Mogilner, C. (2010), "Non-profits are seen as warm and for-profits as competent: first stereotypes matter”, Journal of Consumer Research, Vol. 37 No. 2, pp. 277-291.

Baron, R.M. and Kenny, D.A. (1986), "The moderator-mediator variable distinction in social psychological research: conceptual, strategic, and statistical considerations", Journal of Personality and Social Psychology, Vol. 51 No. 6, pp. 1173-1182.

Berenguer, J., Corraliza, J.A. and Martin, R. (2005), "Rural-urban differences in environmental concern, attitudes, and actions", European Journal of Psychological Assessment, Vol. 21 No. 2, pp. 128-138.

Cheah, L. and Phau, I. (2006), "Interpersonal influence, value orientation and product necessity on purchase of environmentally friendly products", Proceedings of Australian and New Zealand Marketing Academy Conference.

Cheah, I. and Phau, I. (2011), "Attitudes towards environmentally friendly products: the influence of ecoliteracy, interpersonal influence and value orientation", Marketing Intelligence and Planning, Vol. 29 No. 5, pp. 452-472.

Chen, Y.-S. (2010), “The drivers of green brand equity: green brand image, green satisfaction, and green trust", Journal of Business Ethics, Vol. 93 No. 2, pp. 307-319.

Chen, Y.S. (2013), "Towards green loyalty: driving from green perceived value, green satisfaction, and green trust", Sustainable Development, Vol. 21 No. 5, pp. 294-308.

Chen, T.B. and Chai, L.T. (2010), “Attitude towards the environment and green products: consumers' perspective", Management Science and Engineering, Vol. 4 No. 2, pp. 27-39.

Cheung, M.F.Y. and To, W.M. (2019), "An extended model of value-attitude-behavior to explain Chinese consumers' green purchase behavior", Journal of Retailing and Consumer Services, Vol. 50, pp. 145-153.

Dagher, G. and Itani, O. (2012), "The influence of environmental attitude, environmental concern and social influence on green purchasing behavior", Review of Business Research, Vol. 12 No. 2, pp. 104-110.

Deloitte (2014), "Global automotive consumer survey", available at: www.deloitte.com/assets/ DcomUnitedStates/Local\%20Assets/Documents/us_auto_GlobalAutomotiveConsumerStudy_012 314.pdf

Demirel, P., Li, Q.C., Rentocchini, F. and Tamvada, J.P. (2019), "Born to be green: new insights into the economics and management of green entrepreneurship", Small Business Economics, Vol. 52 No. 4, pp. 759-771. 
Eze, U.C. and Ndubisi, N.O. (2013), “Green buyer behavior: evidence from Asia consumers”, Journal of Asian and African Studies, Vol. 48 No. 4, pp. 413-426.

Garson, D. (2002), Guide to Writing Empirical Papers, Theses, and Dissertations, CRC Press.

Hall, J.K., Daneke, G.A. and Lenox, M.J. (2010), "Sustainable development and entrepreneurship: past contributions and future directions", Social Science Electronic Publishing, Vol. 25 No. 5, pp. 439-448.

Han, H., Hsu, L.T., Lee, J.S. and Sheu, C. (2011), "Are lodging customers ready to go green? An examination of attitudes, demographics, and eco-friendly intentions", International Journal of Hospitality Management, Vol. 30 No. 2, pp. 345-355.

Hanna, R.C., Lemon, K.N. and Smith, G.E. (2019), "Is transparency a good thing? How online price transparency and variability can benefit firms and influence consumer decision making", Business Horizons, Vol. 62 No. 2, pp. 227-236.

Joshi, Y. and Rahman, Z. (2015), "Factors affecting green purchase behaviour and future research directions", International Strategic Management Review, Vol. 3 Nos 1/2, pp. 128-143.

Joshi, Y. and Rahman, Z. (2016), "Predictors of young consumer's green purchase behaviour", Management of Environmental Quality: An International Journal, Vol. 27 No. 4, pp. 452-472.

Kaufmann, H.R., Panni, M.F.A.K. and Orphanidou, Y. (2012), "Factors affecting consumers' green purchasing behavior: an integrated conceptual framework", Amfiteatru Economic, Vol. 15 No. 31, pp. 50-69.

Khare, A., Parveen, C. and Mishra, A. (2012), "Influence of normative and informative influence on fashion clothing involvement of Indian women”, Journal of Customer Behaviour, Vol. 11 No. 1, pp. 9-32.

Kim, W.H., Malek, K. and Roberts, K.R. (2019), "The effectiveness of green advertising in the convention industry: an application of a dual coding approach and the norm activation model", Journal of Hospitality and Tourism Management, Vol. 39, pp. 185-192.

Kraft, M.E. (2017), Environmental Policy and Politics, Taylor and Francis.

Lee, K. (2009), “Gender dfferences in Hong Kong adolescent consumers' green purchasing behavior", Journal of Consumer Marketing, Vol. 26 No. 2, pp. 87-96.

Lee, K. (2014), "Predictors of sustainable consumption among young educated consumers in Hong Kong”, Journal of International Consumer Marketing, Vol. 26 No. 3, pp. 217-238.

Lim, W.M., Ting, D.H., Ng, W.K., Chin, J.H. and Boo, W.X.A. (2013), "Why green products remain unfavorable despite being labeled environmentally-friendly?", Contemporary Management Research, Vol. 9 No. 1, pp. 35-46.

Lin, Y.C. and Chang, C.C.A. (2012), "Double standard: the role of environmental consciousness in green product usage", Journal of Marketing, Vol. 76 No. 5, pp. 125-134.

Malik, M.I., Nawaz Mir, F., Hussain, S., Hyder, S., Anwar, A., Khan, Z.U., Nawab, N., Shah, S.F.A. and Waseem, M. (2019), "Contradictory results on environmental concern while re-visiting green purchase awareness and behavior", Asia Pacific Journal of Innovation and Entrepreneurship, Vol. 13 No. 1, pp. 17-28.

Matzler, K., Würtele, A. and Renzl, B. (2006), "Dimensions of price satisfaction: a study in the retail banking industry", International Journal of Bank Marketing, Vol. 24 No. 4, pp. 216-231.

Mittal, D. and Agrawal, S.R. (2016), "Price transparency reflects assurance and reliability", Journal of Retailing and Consumer Services, Vol. 31, pp. 43-51.

Mostafa, M.M. (2006), “Antecedents of Egyptian consumers' green purchase intentions”, Journal of International Consumer Marketing, Vol. 19 No. 2, pp. 97-126.

Mostafa, M.M. (2009), "Shades of green: a psychographic segmentation of the green consumer in Kuwait using self-organizing maps”, Expert Systems with Applications, Vol. 36 No. 8, pp. 11030-11038.

Nunnally, J.C. and Bernstein, I.H. (1994), Psychometric Theory, McGraw-Hill, New York, NY. 
APJIE 14,3

Obayelu, A.E. (2016), "Sustainable consumption and green marketing in developing countries: contemporary perspective using", Handbook of Research on Consumerism and Buying Behavior in Developing Nations, p. 429.

Orobia, L.A., Tusiime, I., Mwesigwa, R. and Ssekiziyivu, B. (2020), "Entrepreneurial framework conditions and business sustainability among the youth and women entrepreneurs", Asia Pacific Journal of Innovation and Entrepreneurship, Vol. 14 No. 1, pp. 60-75.

Padel, S. and Foster, C. (2005), "Exploring the gap between attitudes and behaviour: understanding why consumers buy or do not buy organic food”, British Food Journal, Vol. 107 No. 8, pp. 606-625.

Paradowska, M. (2014), "Problems involved in the development of instruments supporting the creation of sustainable behavior in transport", The Wroclaw School of Banking Research Journal, Vol. 1 No. 39, pp. 255-275.

Qader, I.K.A. and Zainuddin, Y.B. (2011), "The impact of media exposure on intention to purchase green electronic products amongst lecturers", International Journal of Business and Management, Vol. 6 No. 3, pp. 240-248.

Shukla, P. (2011), "Impact of interpersonal influences, brand origin and brand image on luxury purchase intentions: measuring inter-functional interactions and a cross-national comparison", Journal of World Business, Vol. 46 No. 2, pp. 242-252.

Teng, C.-C. and Wang, Y.-M. (2015), "Decisional factors driving organic food consumption: generation of consumer purchase intentions”, British Food Journal, Vol. 117 No. 3, pp. 1066-1081.

Vermeir, I. and Verbeke, W. (2008), "Sustainable food consumption among young adults in Belgium: theory of planned behaviour and the role of confidence and values behavior and the role of confidence and values", Ecological Economics, Vol. 64 No. 3, pp. 542-553.

Xu, X., Hua, Y., Wang, S. and Xu, G. (2020), "Determinants of consumer's intention to purchase authentic green furniture", Resource, Conservation and Recycling, Vol. 156, pp. 104721.

Young, W., Hwang, K., McDonald, S. and Oates, C.J. (2010), "Sustainable consumption: green consumer behaviour when purchasing products", Sustainable Development, Vol. 18 No. 1, pp. 20-31.

Zafar, S., Aziz, A. and Hainf, M. (2020), "Young consumer green purchase behavior", International Journal of Marketing Research Innovation, Vol. 4 No. 1, pp. 1-12.

\section{Corresponding author}

Raheem Bux Soomro can be contacted at: rb.soomro@salu.edu.pk

For instructions on how to order reprints of this article, please visit our website:

www.emeraldgrouppublishing.com/licensing/reprints.htm

Or contact us for further details: permissions@emeraldinsight.com 